Article

\title{
A Comprehensive Construction and Demolition Waste Management Model using PESTEL and 3R for Construction Companies Operating in Central Asia
}

\author{
Ali Turkyilmaz $1,2, * \mathbb{1}$, Mert Guney ${ }^{2,3}$, Ferhat Karaca ${ }^{2,3}$, Zhanar Bagdatkyzy ${ }^{1}$, \\ Aiganym Sandybayeva ${ }^{1}$ and Gulzat Sirenova ${ }^{1}$ \\ 1 Master of Engineering Management Program, School of Engineering, Nazarbayev University, 010000 Astana, \\ Kazakhstan; zhanar.bagdatkyzy@nu.edu.kz (Z.B.); aiganym.sandybayeva@nu.edu.kz (A.S.); \\ gulzat.sirenova@nu.edu.kz (G.S.) \\ 2 Department of Civil and Environmental Engineering, Nazarbayev University, 010000 Astana, Kazakhstan; \\ mert.guney@nu.edu.kz (M.G.); ferhat.karaca@nu.edu.kz (F.K.) \\ 3 The Environment and Resource Efficiency Cluster (EREC), Nazarbayev University, 010000 Astana, \\ Kazakhstan \\ * Correspondence: ali.turkyilmaz@nu.edu.kz
}

Received: 19 January 2019; Accepted: 19 February 2019; Published: 15 March 2019

check for updates

\begin{abstract}
The construction industry in Central Asia has shown rapid growth in the last decade due to an economic boom, leading to high construction \& demolition waste (C\&DW) generation accompanied by waste management operations falling behind worldwide best practices. The present study first employs a comprehensive environmental screening approach, PESTEL analysis, to identify and assess critical external and internal factors that can affect C\&DW management in a leading Central Asian construction company (headquarters in Kazakhstan, the country with the largest economy in the region). Then, a case study is performed using $3 R$ (reduce-reuse-recycle) principles and subjecting this company. Current international practices tailored to the given context are provided, existing company practices and applied improvements are discussed and prioritized improvements with implied sustainability benefits are proposed. The findings and recommendations are applicable especially to other construction companies operating in Central Asia that would ensure more sustainable C\&DW management operations in the future.
\end{abstract}

Keywords: 3R strategy; C\&DW; construction \& demolition waste; solid waste management; waste management hierarchy; waste minimization

\section{Introduction}

According to "Global Waste Management Outlook" prepared by United Nations Environmental Programme (UNEP) and International Solid Waste Association (ISWA), solid waste (SW) generated by areas such as commerce, households, construction industry and other industries makes up seven to ten billion tons of waste annually. Almost $85 \%$ of the waste generated worldwide is disposed to landfills and the degree of waste reuse and recycling is critically low [1]. A significant amount of industrial waste is created by the construction industry which is generally categorized as construction \& demolition waste (C\&DW) which has become a concern of governments and consequently, of construction companies [2,3]. The construction industry is estimated to be accountable for using around two-fifths of the world's energy and materials flow, one-sixth of freshwater reserves and one-quarter of global wood harvest [4] while contributing to $13-30 \%$ to total waste generated worldwide [5]. The exact figures regarding the share of C\&DW in total SW stream can be very high and also vary significantly 
among different countries/continents, for example, in Europe, 25-30\% in 2016 [6]; in Hong Kong, 23\% in 2014 [7]; in the United Arab Emirates, 80\% in 2010 [8]; and, in Singapore, 59\% in 2011 [9].

The high speed of urbanization entails on the increased demand for housing and transportation; therefore, the volume of C\&DW continues its increase [10]. Referring to waste generated in the process of dismantling, repair, and/or construction of buildings, the conventional preferred way of C\&DW management-in most countries-is disposal to designated landfills. It should be noted that the disposal to landfill is associated with costs, the largest and the most visible ones being transportation costs and landfill tipping fees [11] for example, collection and sanitary landfill disposal costs for lower-mid income countries (such as Kazakhstan) being in the range of 30-75 USD and 15-40 USD, respectively; while for high income countries being in the range of 85-250 USD and 40-100 USD, respectively [12]. Various concerns on environmental pollution and rapid depletion of natural resources as well as sustainability programs being implemented have urged many other countries to set aside the approach of landfill disposal and rather consider alternative ways for a more efficient waste management such as: applying life cycle assessment to municipal solid waste management especially in European and some Asian countries for waste disposal reduction, ref. [13] reducing illegal waste via C\&DW models using system dynamics and grey model theory [14] and mixing inorganic construction wastes containing $\mathrm{CaO}$ (e.g., waste gypsum) to portland cement in appropriate proportions to promote recycling and thus to reduce disposal [15]. On the contrary, companies are seeking for more efficient ways of waste management most often in terms of economical sustainability more than in terms of environmentally and socially sustainable development, leading mainly to cost-cutting strategies [16].

As a recently and rapidly developing area of the world, Asian countries require significant improvements in waste management including C\&DW management. Narrowing down to Central Asian countries, a projection to this part of the world indicates that particularly the cities with lower economic status would experience difficulties in waste management as a result of expected one-fold increase in their SW generation in the next 15 to 20 years. The region of Central Asia comprises five former Soviet republics: Kazakhstan, Kyrgyzstan, Tajikistan, Turkmenistan and Uzbekistan. They are landlocked countries on the Eurasian/Asian continents, experiencing significant development in multiple sectors with particular rising concerns on plastic waste, hazardous waste, e-waste, C\&DW and overall municipal waste management practices during the last decade and are suffering from not having proper waste management systems installed in their urban environments [17].

Among the Central Asian countries, the construction industry has been experiencing a boost especially in and around Kazakhstan since 1990's. Kazakhstan is the politically leading country in Central Asia whose economy also shows the strongest performance with a growth momentum [18]. The construction sector has been one of the drivers of the economic growth in Kazakhstan while the research that has been carried out in the area of industrial and municipal SW management practices in Kazakhstan is quite limited [19] and no published research related to C\&DW could have been found. The Environmental Code of the Republic of Kazakhstan is the main directives that regulate the waste management -including construction and demolition waste managementin Kazakhstan [20]. Besides, issued in 2014 by the Ministry of Environment and Water Resources, the Program of Modernization of Municipal Solid Waste Management aiming at improving the management and control of municipal solid waste system also deals with the issues, management and regulations linked to the country-wide construction waste management practices. Both these programs with the support of other governmental and civil initiatives are targeting the objectives of the "Concept of transition of Kazakhstan to a Green Economy" [21].

Kazakhstan has more than 4000 landfills, only ten percent of which are legally authorized to operate [22]. In Kazakhstan, a large number of international and national contractors perform in the construction sector, bringing their unique practices, attitudes and behaviours regarding waste management; differing based on the size and country-specific experience of the contractor which directly affect the amount of waste generation and the quantities reduced, reused and recycled. 
In general, it is possible to mention a work culture that is similar to what is prevalent in post-Soviet states/countries and a general influence and heritage of shared practices from the past and the present.

The current situation in Central Asia regarding C\&DW management including specific needs for improvement development have not yet been investigated and precise strategies of improvement have not yet been addressed. In Central Asia and particularly in Kazakhstan, the rapid economic growth (a GDP growth for Kazakhstan from 18.3 billion USD in 2000 to 163 billion USD in 2017) significantly driven by a booming construction industry (coupled with evidence indicating (a) a general lack of good waste management practices in the region and (b) an expected increase of waste generation as a result of increasing GDP [12] points out to an important need for (1) clearly identifying existing challenges and barriers specific to the region and then (2) recommending best practices and improvements for C\&DW management tailored to specific needs in the region. That being said, to the authors' knowledge, there is no published research on C\&DW management practices in Central Asia. The first objective of the present study is (1) to suggest a comprehensive C\&DW management approach by screening via PESTEL (standing for Political, Economic, Socio-cultural, Technological, Environmental and Legal aspects) analysis [23] the current external and internal factors along with international practices, which would provide a good comparison basis with practices which fit in the Central Asia context regarding $C \& D W$. Then, a case study has been performed by focusing on the waste management hierarchy (i.e., 3R strategy: reduce-reuse-recycle) which is also fundamental to effective C\&DW management. This has been done on one of the biggest construction companies in Kazakhstan, presuming that it effectively represents the practices in other construction companies in Kazakhstan as well as in the rest of Central Asia. The present study, then, aims to (2) investigate and discuss the status quo (i.e., the existing practices) based on $3 \mathrm{R}$ principles and an economic analysis and (3) propose prioritized improvements with identified economic benefits, which may help improve the current performance in waste management via a proposed waste management model. These will be applicable not only to the specific company but also to other companies and countries especially in Central Asia, helping for more sustainable future operations.

\section{Methodology}

The initial stage of this study was based on a literature review and investigation aiming to identify the waste generation mechanisms and global best practices which fit the dynamics of the construction industry in Kazakhstan context (external factors) and company operational profile (internal factors). After that, in order to assess the C\&DW management performance of the company from a broader perspective (including the drivers and the barriers), a comprehensive C\&DW model was developed using a combination of PESTEL and 3R. A PESTEL analysis was employed for the external (e.g., countryand sector-level) and organizational (company-level) assessment, whereas the $3 \mathrm{R}$ approach was used for the operational level assessment (company-level). Figure 1 summarizes the methodology of the present study.

Known as a comprehensive environmental screening approach, PESTEL analysis aims to identify and assess the critical macro-environmental factors that can affect the working conditions in an industry and performance of the firms operating in that industry [24]. PESTEL analysis has been successfully used as an effective framework for strategic level decision making $[23,25]$ and has been recommended as a powerful approach for the development of reliable future scenarios and effective business models [26].

The construction industry can be characterized by a complex and diverse interrelations of various macro-environmental factors that directly or indirectly affect the company's operations. PESTEL can also be employed as an effective tool for understanding the key external macro parameters that are likely to impact the construction sector in Kazakhstan and as well as on the success of the company's efforts (including C\&DW management) in medium- and long-term periods. Therefore, in the present study, the external and organizational drivers as well as the barriers of C\&DW management for the $\mathrm{CC}$ and its performance on management have been evaluated using PESTEL through the focus-group studies and interviews with the participation of the experts in the field and the representatives of 
the CC, discussing their performance and as well as their fit onto each other. This may help identify weak spots of the firm that needs to be addressed to improve the current efficiency.

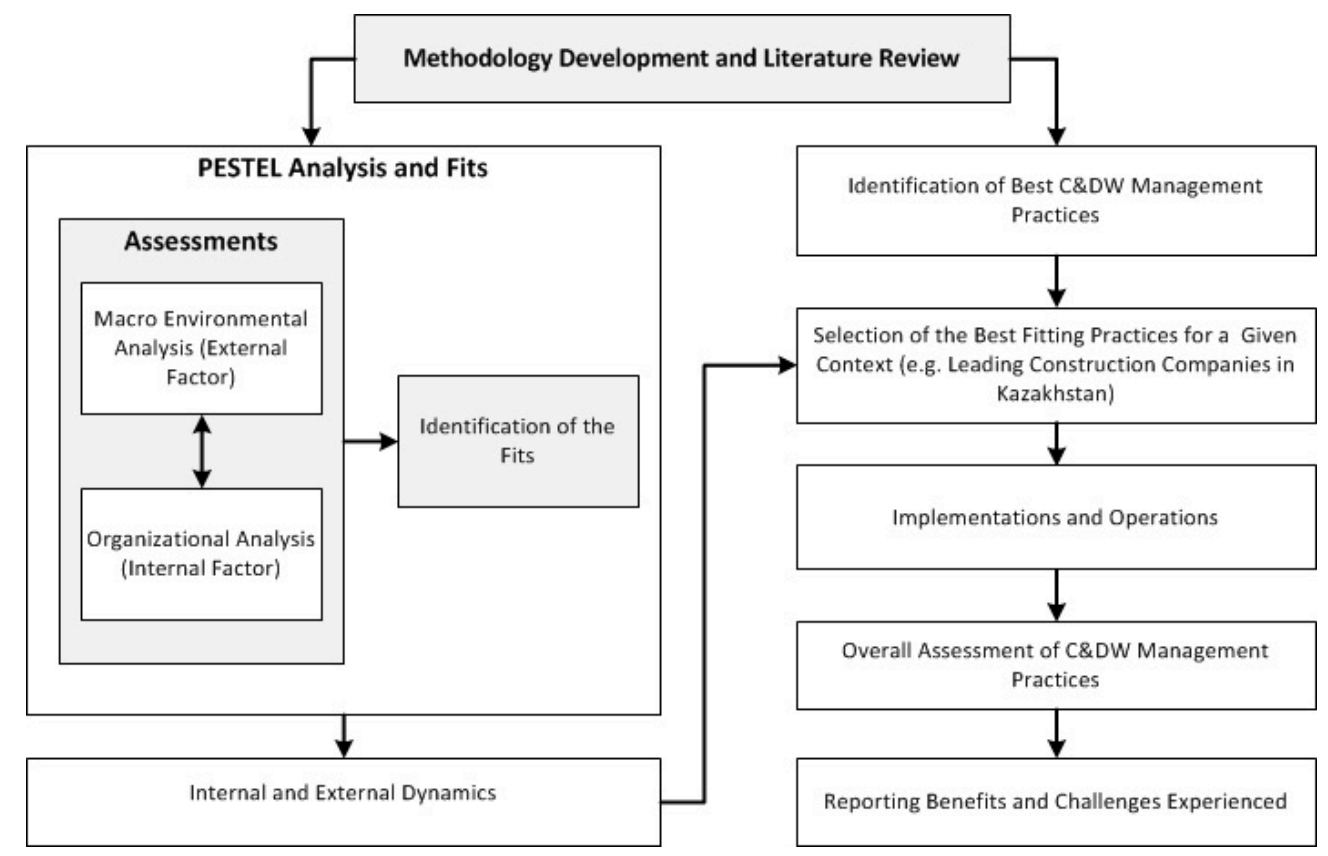

Figure 1. Methodology of the present study.

Four main elements; tasks, people, formal and informal organizations were considered for the internal assessment. With a complex hierarchical organizational structure, self-government prevails across every division and every construction site within the division. For instance, when the CC initiated the construction waste sorting campaign on-site and the program was only partially successful mainly because some construction sites actually implemented the suggested sorting practices, whereas others demonstrated negligence. Similarly, the level of awareness and attitude of people on waste management is a critical component in waste management and can be improved by appropriate activities including workforce search, training, education and similar sort of other practices [27,28].

In order to understand the level of awareness on C\&DW management as well as the overall attitude of people on waste management in the CC, a semi-structured in-depth interview, a qualitative research technique that involves intensive interviews with a small number of respondents, has been carried on with 15 experienced employees ( 5 managers and 10 on-site workers). The main focus during the interviews was particularly on (1) if the workers are aware of CD\&W management strategies and practices, (2) if they believe that the recycling on-site is possible in CC facilities (3) the most effective ways to reduce the waste (4) if they think that they are informed well on waste management and, finally, (5) the main reasons to not to apply waste management properly in the facilities of CC.

The integrated waste management hierarchy includes the following main stages: Reduce, Reuse, Recycle, Compost, Incinerate and Landfill. These stages have been chosen and hierarchically sorted based on their negative environmental impact that is, Reduce having the lowest to Landfill being the highest. Choosing sustainable solutions to apply to waste management problems is a process based on the availability and applicability of various options sorted, reviewed and then selected according to the provided hierarchy. The impact on environment of a stage increases through the lower steps of the hierarchy (i.e., Reduce has the lowest impact on the environment whereas Landfill has the greatest) [29]. The most important contributors to waste minimization are Reduce, Reuse and Recycle, also known as the 3R strategy [30-32]. 3R strategy has also served as a general guideline for this case study as it is the most common in many countries and resulting in significant decrease in C\&DW and especially in high recycle rates. 


\section{Case Company (CC)}

The case company (CC) studied for this research is one of the biggest and fastest-growing construction enterprises with its numerous ongoing and upcoming residential, infrastructure and industrial construction projects in Kazakhstan and Central Asia. Taking into account that the CC operates almost in all geographical regions of the country (as well as its operations also extend through the rest of Central Asia) for various construction projects including residential, infrastructure and industrial buildings including numerous partnered projects, it could be considered as a very good overall representative of modern construction companies operating in Kazakhstan (also a good representative of the Central Asian scene).

According to waste composition data provided by the $\mathrm{CC}$, the waste from their construction operations is comprised of mostly potentially reusable or recyclable materials (inert (60\%) and non-inert waste $(35 \%)$ ) and only $5 \%$ is normally required to be disposed to landfill (waste composition presented in detail in Table 1). The inert waste in this context specifically refers to materials or items that do not undergo any significant physical, chemical or biological transformation; but not including any hazardous or green material. Although $95 \%$ of the CC's C\&DW could be potentially recycled or reused as reported by the company, most of it currently goes to landfill. Especially the high quantity of inert waste that is more than half of all generated waste indicates a great potential for reuse or recycle. This would eventually not only reduce the costs for C\&DW management but would also contribute to the CC's revenue and increased good reputation.

Table 1. Waste composition data for C\&DW generation at the CC.

\begin{tabular}{cc}
\hline Waste Constituent & $\mathbf{\%}$ \\
\hline Inert reusable/recyclable (total) & $\mathbf{6 0 . 0}$ \\
\hline Concrete & 18.6 \\
Bricks & 18.6 \\
Autoclaved cellular concrete & 4.2 \\
Façade materials & 3.6 \\
Decoration materials & 15.0 \\
\hline Non-inert reusable/recyclable (total) & $\mathbf{3 5 . 0}$ \\
\hline Metal & 20.3 \\
Timber & 10.9 \\
Paper & 1.8 \\
Plastic & 1.8 \\
Glass & 0.4 \\
\hline Other, non-reusable/recyclable (total) & 5.0 \\
\hline
\end{tabular}

\section{Results and Discussion}

\subsection{External and Internal Drivers of CEDW Management in the CC}

The preliminary finding of the PESTEL (Table 2) analysis on the external factors is that some external factors that may influence the performance of the CC indeed did theoretically exist but they do not affect in practice positively the CC's performance in waste management due to a lack of strong regulations and/or enforcement in this field. As an example, there is an environmental code (Art. 301, item 18 in Environmental Code of the Republic of Kazakhstan) [20] that restricts the landfill disposal of certain construction materials but it is not followed by construction companies. Also, the overall market in the country related to waste management does not correspond to the level of generated waste. 
Table 2. Results of PESTEL analysis for current C\&DW practices at the Case Company (CC).

\begin{tabular}{|c|c|c|}
\hline Political Factors & Economic Factors & Socio-Cultural Factors \\
\hline $\begin{array}{l}\text { - } \quad \text { Existing political stability } \\
\text { Residential construction } \\
\text { defined as one of the main } \\
\text { directions of the } \\
\text { Government's development } \\
\text { strategy "Kazakhstan-2030" } \\
\text { - State program "Development } \\
\text { of construction industry and } \\
\text { production of construction } \\
\text { materials for 2010-2014" } \\
\text { State program for the } \\
\text { "Modernization of the Solid } \\
\text { Waste Management System } \\
\text { for 2014-2050" }\end{array}$ & $\begin{array}{l}\text { - Cost to dispose in landfill } \\
\text { lower than recycling } \\
\text { Low wages resulting in a } \\
\text { high turnover rate of } \\
\text { on-site workers } \\
\text { - } \quad \text { Lack of a stable and } \\
\text { responsive market for } \\
\text { recycling of waste } \\
\text { - } \quad \begin{array}{l}\text { Negative consumer } \\
\text { perception for materials }\end{array} \\
\text { made of recycled aggregates } \\
\text { Low landfill tipping fees }\end{array}$ & $\begin{array}{l}\text { - } \quad \text { Poor knowledge on waste } \\
\text { recycling/reuse } \\
\text { Low level of motivation for } \\
\text { waste } \\
\text { sorting/recycling/reusing } \\
\text { - Conservative culture of } \\
\text { construction design loyal to } \\
\text { out-of-date practices } \\
\text { Low level of collaboration for } \\
\text { waste minimization between } \\
\text { managers and } \\
\text { on-site workers }\end{array}$ \\
\hline Technological Factors & Environmental Factors & Legal Factors \\
\hline $\begin{array}{l}\text { Lack of specialized and } \\
\text { affordable equipment for } \\
\text { on-site reuse of materials } \\
\text { Lack of recycling plants in } \\
\text { the country } \\
\text { No established prefabricated } \\
\text { design and } \\
\text { construction technologies }\end{array}$ & $\begin{array}{l}\text { Existing practices of illegal } \\
\text { (wild) dumping and on-site } \\
\text { filling at some regions in } \\
\text { the country } \\
\text { Existing practices of disposal } \\
\text { to landfills (normally not } \\
\text { allowed by law) at some } \\
\text { regions in the country }\end{array}$ & $\begin{array}{l}\text { - Lack of strong policies and } \\
\text { regulations against } \\
\text { landfill disposal } \\
\text { - Lack of incentives for } \\
\text { - } \quad \text { Enviste management } \\
\text { not enforced: “Construction } \\
\text { materials' wastes are } \\
\text { unacceptable for landfills - } \\
\text { Art.301, item } 18 \text { of the State } \\
\text { Environmental code" }\end{array}$ \\
\hline
\end{tabular}

Results from the interviews has shown that less than half of the interviewees were aware of C\&DW management and related practices. The majority, after a short introduction, expressed that proper planning of resources at the initial stage, sorting and recycling are most important and effective practices among others for the CC. The majority of the on-site workers agree on that additional information should be provided regarding the waste management, highlighting that they are aware that they have a low understanding of waste management and feel the need to improve through the appropriate training and practices. In addition, both managers and on-site workers believe that a lack of motivation is another major reason why waste management is not done properly on the site. The results of the interview suggest that (a) increasing the awareness for the 3R strategy is advisable for all employees of CC, (b) that additional training should be provided regarding the waste management, (c) and that the employee motivation should be handled for more effective waste management. The CC immediately responded to the survey results by conducting training and knowledge sharing sessions for more than 500 of its employees as well as for the employees of their contractors to increase their awareness about waste management and particularly encourage them to sort waste on-site. It should be noted that the existing high employee turnover rate will require frequent repetition of these training in the future to keep the workforce well trained about the sustainability of C\&DW management operations.

From the observed cultural point of view in the region, waste management has not previously been a major concern in the civil society of Kazakhstan, nor in corporations such as the CC. The observed ignorance about waste management both in public and private sectors lead to the fact that 
society has also not become a "green society" by any means, demonstrating an overall low awareness about waste management.

The CC, in the past, has been more reactive to C\&DW problems rather than proactive that is, by responding to emerging problems only after their occurrence. This was caused by an absence of a waste management vision and a consistent methodology and by a lack of experience resulting in missing best practices and competency in waste management. The CC, thus, focused on the elimination of existing waste problems rather than trying to reduce the waste from the beginning as well as planning for reuse and recycling. According to the CC's financial data on purchased materials and on waste management for the period of 2014-2015, the annual increase in the discarding costs for construction waste was $70 \%$, while the rate of annual increase of purchased materials was around $30 \%$. This imbalance has made the CC start focusing on proper waste management practices as of 2016 by implementing a waste management program.

The analysis of PESTEL shows that there is an "official" vision in Kazakhstan towards establishing waste management guidelines. However, the low level of technological factors prepossessing the recycling of waste, the low level of awareness and an absolute absence of incentive from legal and economical perspectives proved the opposite. Currently, by still mostly dealing with the existing waste only (e.g., sorting), the CC's waste management can be perceived as reactive, rather than proactive. This is caused by:

1. An absence of consistent waste management vision and approach

2. An absence of common internal waste management methodology

3. A lack of experience, best practices and competency in waste management

After the analysis of each individual element of congruence model, the relationship between each different component, also known as a 'Fit,' is presented in Figure 2 and can be concluded as follows.

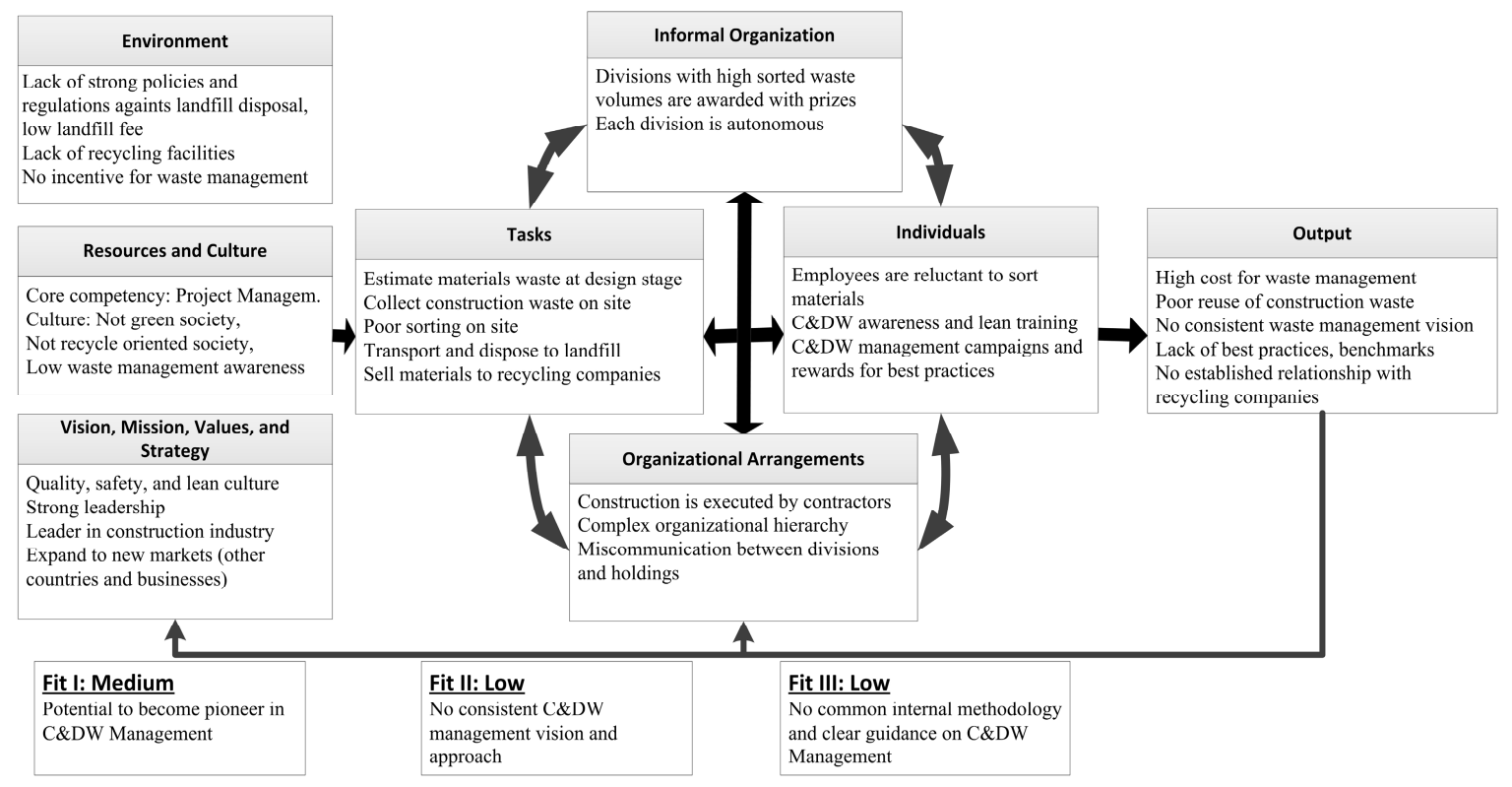

Figure 2. Drivers and barriers (PESTEL) analysis and individual elements of congruence model along with their relationship between different component fits.

Fit 1: How well the CC's mission, vision, values and goals fit with external factors?

Medium: The CC's existing strategy focuses on growth and expansion to new markets. Given low opportunities for efficient waste management in Kazakhstan, the CC's mission, vision, values and goals fit well with external factors. However, given the CC's goal to become one of the 100 largest companies in the construction sector in the world, it has a lot of room for improvement of their waste 
management program to perform in markets that will provide different external factors. Functioning under such conditions would give them, at the same time, an opportunity to become pioneers in C\&DW management in Kazakhstan.

Fit 2: How well the internal organization fits with the CC's vision, mission and goals?

Low: The CC particularly values lean management principles, which by definition assumes a constant striving to minimize all sorts of "waste" (time, labour, etc.). Although the CC showed some success in the application of lean resulting in improved processes and decreased labour costs, this did not translate to decrease in SW as the company lacks a consistent vision that will result in efficient C\&DW management.

Fit 3: How well the components of internal organization fit with each other?

Low: This has been induced by factors such as a complex organizational hierarchy, highly autonomous divisions, a traditional approach design and construction and participation of a limited number of personnel, which results in an absence of common internal methodology and a clear guidance on waste management.

\subsection{R-Based CEDW Management Practices and Results}

A summary of the potential 3R strategies in the construction value chain along with the related applications used by the CC are presented in Figure 3. Also, to provide a summary, the most significant benefits and challenges we have experienced during the implementation of $3 \mathrm{R}$ practices are summarized in Table 3. A detailed discussion on the selected proposed methods as well as experiences from tried 3R applications are presented in the following three subsections.

\section{C\&DW Management Practices (3R)}

\begin{tabular}{|c|}
\hline REDUCE \\
\hline $\begin{array}{c}\text { Regulating/standardizing management } \\
\text { plans of hazardous materials }\end{array}$ \\
\hline $\begin{array}{l}\text { Identifying and quantifying amounts } \\
\text { of C\&DW and treatment needs }\end{array}$ \\
\hline Improving logistics of materials \\
\hline $\begin{array}{l}\text { Specifying actions for every type of } \\
\text { waste }\end{array}$ \\
\hline $\begin{array}{l}\text { Establishing on-site waste sorting } \\
\text { campaigns }\end{array}$ \\
\hline $\begin{array}{l}\text { Establishing minimum waste sorting } \\
\text { and management requirements }\end{array}$ \\
\hline Defining responsibilities \\
\hline Monitoring waste generation \\
\hline $\begin{array}{l}\text { Using prefabricated materials and } \\
\text { elements }\end{array}$ \\
\hline $\begin{array}{l}\text { Using modern methods of } \\
\text { construction }\end{array}$ \\
\hline Employing C\&DW management plans \\
\hline
\end{tabular}

\begin{tabular}{|c|}
\hline REUSE \\
\hline Renting and reusing of auxiliaries \\
\hline Reducing use of onsite cuttings \\
\hline $\begin{array}{c}\text { Maximizing production of high quality } \\
\text { recycled aggregate }\end{array}$ \\
\hline $\begin{array}{c}\text { Using same materials for same } \\
\text { application }\end{array}$ \\
\hline $\begin{array}{c}\text { Reusing drywall in fertilizer and } \\
\text { compost production and/or in new } \\
\text { drywall manufacturing }\end{array}$ \\
\hline $\begin{array}{c}\text { Applying innovative storage and } \\
\text { handling practices }\end{array}$ \\
\hline $\begin{array}{c}\text { Establishing waste separation and } \\
\text { collection strategies }\end{array}$ \\
\hline
\end{tabular}

\begin{tabular}{|c|}
\hline RECYCLE \\
\hline $\begin{array}{c}\text { Recycling waste plasterboard and } \\
\text { other sources of waste gypsum }\end{array}$ \\
\hline $\begin{array}{c}\text { Harvesting materials or auxiliaries at } \\
\text { construction or demolition site }\end{array}$ \\
\hline $\begin{array}{c}\text { Limiting number of materials and } \\
\text { components and easy-to-separate } \\
\text { materials }\end{array}$ \\
\hline $\begin{array}{c}\text { Driving innovation on recycling } \\
\text { opportunities }\end{array}$ \\
\hline $\begin{array}{c}\text { Using recycled material for business- } \\
\text { to-business refund system }\end{array}$ \\
\hline Estimating and minimizing costs \\
\hline
\end{tabular}

Figure 3. Feasible 3R strategies for Central Asian context in construction value chain and related applications used in the case study company.

\section{LEGEND}

At least one application exists Feasibility assessment completed No applications yet to be done 
Table 3. Most significant benefits and challenges of 3R strategy elements experienced at the CC.

\begin{tabular}{|c|c|c|}
\hline & Most Significant Benefits & Challenges \\
\hline Reduce & $\begin{array}{l}\text { - } \quad \text { Can be implemented independent of } \\
\text { third parties } \\
\text { - } \quad \text { May lead to significant cost savings } \\
\text { - } \quad \text { Automatically decreases future waste } \\
\text { management efforts }\end{array}$ & $\begin{array}{l}\text { - Needs to be implemented mainly at the } \\
\text { design stage }\end{array}$ \\
\hline Reuse & $\begin{array}{l}\text { - Reduces some of the need for new } \\
\text { materials purchase }\end{array}$ & $\begin{array}{l}\text { - Lower potential cost savings compared to } \\
\text { Reduce and Recycle } \\
\text { May require additional resources or } \\
\text { third-party involvement (equipment } \\
\text { and/or expertise) } \\
\text { - } \quad \text { Properties of individual materials are } \\
\text { important for possible implementation }\end{array}$ \\
\hline Recycle & $\begin{array}{l}\text { - Highest potential cost savings among } \\
\text { 3R elements } \\
\text { - } \quad \text { May create revenue by selling material } \\
\text { - } \quad \text { say help create a waste-free construction } \\
\text { May help build a positive reputation for } \\
\text { the company }\end{array}$ & $\begin{array}{l}\text { - May require additional resources or } \\
\text { third-party involvement (equipment } \\
\text { and/or expertise) } \\
\text { - } \quad \text { Requires good sorting practices }\end{array}$ \\
\hline
\end{tabular}

\subsubsection{Practices Based on Reduce Strategy}

Reduce may be seen as the core step in C\&DW management. The best way to reduce waste is to not produce it and therefore this step must ideally be started at an early design stage of the project [33]. The extant literature shows that an improper design is the main source of waste generation, such as excessive cut-offs [34-36]. The design stage usually requires a comprehensive, conscious and innovative approach. In general, there are many ways to reduce C\&DW; however, the most common and effective ones are the use of building information modelling (BIM) technologies and the use of prefabricated materials.

BIM technologies comprise of digital modelling of a building containing all technical (geometry, quantity and characteristics of materials) and functional (schedule, costs, resources) information about it. BIM is used for improved planning and scheduling [37] as well as for avoiding design errors and reworks $[38,39]$ at the same time helping identifying clashes early in the project phase. The value from the application of BIM can be significant reduction in mechanical change orders via BIM-based design validation [39].

The application of BIM was found reasonable and acceptable by the CC and is currently at the initial stage of the implementation. The CC adheres the state-of-the-art BIM technologies and fully acknowledges the benefits of BIM technologies, including its impact on the reduction of waste and subsequent improvement in C\&DW management. There are also other potential benefits stated by the CC from the application of BIM which are difficult to measure, such as better just-in-time delivery and better communication among project stakeholders. Finally, BIM provides the CC with precise measurements of components, the primary data required to make prefabricated materials. In the CC, it is yet difficult to precisely quantify the benefits from the use of BIM, however a significant improvement has already been achieved by identifying large numbers of design errors of various sizes which would have had a significant impact in terms of rework and by identifying discrepancies between different drawings. After the initial implementation, the CC assumes that almost $90 \%$ of the prevented waste was of concrete. 
The method of using prefabricated materials for construction also known as Industrialized Building Systems (IBS) involve materials or components which are manufactured and assembled separately from the construction site in a specialized facility where several materials are joined to form a ready component. Compared to the conventional way of using raw materials for on-site components production, the use of prefabricated materials allows reducing waste generation on-site as well significantly reducing construction time. Typical examples of prefabricated materials are precast facades, staircases, partition walls, bathrooms, balconies and slabs. Quantitative advantages of using prefabricated materials have been studied and it was estimated that their use replaces $70 \%$ of finishing works on-site and reduces waste associated with timber by $74-87 \%$ and associated with concrete by $51-60 \%[40,41]$. A comparison study between conventional, mixed and IBS constructions by Lachimpadi, et al. (2012) [42] states that the conventional construction, where all materials were cast on-site, produces 1.5 times more waste than mixed construction and three times more than IBS.

There is a limited application of prefabricated materials in the case of the CC and all concrete and monolithic jobs are cast on-site using timber formwork. The low level of application of prefabricated materials can be explained by the fact that casting concrete on-site is cheaper, though it takes longer time to manufacture and produces more waste. This is at least partly due to the absence of local facilities that produce prefabricated materials. Therefore, such materials need to be ordered from abroad which increases costs, while imports from the neighbour with the most active commercial relationship Russia would keep that increase to a minimum. Another reason is technological disputes, suggesting that the application of prefabricated materials in construction could lead to more faulty connections as well as cause more leakage problems which will eventually influence stability and strength of the structures. However, this is rather a quality issue as these potential problems have been previously avoided in many cases by focusing on practices leading to building proper joint connections during prefabricated construction.

Although there are currently no facilities for producing prefabricated materials in Kazakhstan, some prefabricated materials such as facades or partition walls can be ordered from abroad, the most prominent candidate being Russia. As currently all concrete casting is performed on-site using formworks, it is also reasonable to propose using half-prefabricated materials (mixed construction), such as partition walls or facades, instead of proposing a total switch to purely prefabricated materials. Using half-prefabricated materials may allow a smooth gradual transition from conventional to prefabricated construction. However, the use of this option also depends on the context and other external factors such as cost, schedule, procurement and quality. For now, it is more preferable to use half-prefabricated materials on construction sites with tighter schedules due to the additional time saving benefits which may balance higher costs. Finally, yet importantly, using half-prefabricated materials is a recent practice that is being established in Kazakhstan, already in the process of being adopted in some construction sites by different companies with success.

With their partially successful initial program for waste management, the CC managed to produce 60,000 tons of waste in 2016, down from 75,000 tons in 2015. It can be assumed that at the Reduce stage, effectively following BIM based procedures would help reduce the amount of the waste by around $15 \%$ and the use of half-prefabricated materials for construction would lead to an additional 1.5-fold reduction as reported by the literature [42], leading to a total potential reduction of waste from 60,000 tons to 34,000 tons if both measures are fully implemented. In should be noted that the CC is already implementing BIM and its competitors are recently successfully implementing the use of half-prefabricated materials to their construction activities, therefore, the suggested reduction potential is achievable.

It is particularly important to understand the value of applying BIM systems within C\&DW management. The deployment of BIM technologies in the present case study is currently at its initial stages. It is not a rapid process since it requires a lot of customization, training and set-up. Once successfully implemented, further achieved C\&DW reductions will enhance more the significance of 
the Reduce stage and the reductions at this stage will automatically lessen the need for/significance of Reuse and Recycle stages.

\subsubsection{Practices Based on Reuse Strategy}

As part of the 3R strategy, the Reuse initiative aims to extend a material's lifecycle via repeated use for the same purpose as well as benefitting opportunities for use for secondary purposes. Reuse of materials in C\&DW management is applicable on-site during construction or after the construction has been completed. This usually requires additional equipment and workforce and is highly dependent on C\&DW material properties and its volume [43]. In the scope of the present study, concrete and drywall have been considered for the Reuse stage.

Crushed concrete can be used as sub-base and base in road construction or in foundations, as aggregate for concrete or asphalt, as drainage material and as cover material [43]. In order to maintain the properties of the material to be produced, the use of recycled aggregate should be limited and the maximum ratio that can be used is based on the final purpose, for example: $1 \%$ recycled concrete for foundation, supporting (retaining) walls, reinforced concrete beam at ground level, pile cap; $15 \%$ applied for haunch support and drainage layer; $50 \%$ for rock-fill and filter layer; $15 \%$ for sub-base and $20 \%$ for block paving [44].

In the CC, on-site crushing of concrete and its reuse in the construction of temporary roads has been previously considered. To achieve this, two pieces of concrete crushing equipment (CCE) have been acquired and installed. However, the use of CCE's ultimately did not lead to any economic benefit. According to project managers, the savings from the use of CCE's were not enough to cover the costs of operation. Based on this, the option of processing construction debris using CCE's is a good option for environmental sustainability but does not currently offer any additional economic benefit if used in road construction. From the practice, it could be assumed that $80 \%$ of the concrete waste generated can be reused or recycled by CCE and then be reused for purposes other than road construction. For example, the production of concrete with acceptable quality is possible with replacement ratios of aggregate with recycled concrete up to $30 \%$ [44].

The gypsum drywall has several alternative uses and the generated waste of drywall in the construction industry can easily be reused and recycled as it is commonly recovered uncontaminated. It can be recycled into new drywall or reused after processing as a soil and fertilizer amendment. It is also an effective compost additive for areas that have a low level of nutrients of sulphur and calcium.

Gypsum increases the level of calcium in compost and can also help neutralize the acidity that might be present in compost mixture. The potential challenges with using gypsum as additive are a higher need for effective monitoring the temperature, moisture and oxygen levels in compost mixture in order to avoid conditions favouring anaerobic decomposition. In addition, the obtained product should be controlled and monitored to have fewer paper-like pieces that are not desired by the end consumer. However, this is not a significant limitation in most cases, according to The Clean Washington Centre, these particles are unnoticeable in compost mixtures that have less than $30 \%$ of gypsum drywall [45].

Finally, the waste drywall waste can be given away to third parties (business-to-business) interested in building affordable structures of various purposes or in repurposing drywall for several uses in agricultural operations. This is a viable alternative for the country matching its developing economy status and will lead to savings for both the CC due to the avoidance of transportation and landfilling costs and the third parties due to reduction in material purchasing costs.

\subsubsection{Practices Based on Recycle Strategy}

Recycling is an important aspect of C\&DW management, even though it is the last preferable option in the generality of the $3 R$ hierarchy. It is also one of the commitments to the environment that is most visible to the public. Finally, the production of recycled materials on a lifecycle basis is less expensive than materials from primary sources. While Recycle is not a new term to some 
societies, to the majority of the population in Central Asia, it is relatively so, having been introduced to citizens only in the recent century mainly via the government with the help of mass media. Since the times of the Soviet Union, the population has been used to the practice of waste either being directly disposed to large landfills or incinerated in certain scenarios. To reduce waste disposal in landfills, some recycling facilities have been built in Kazakhstan. However, their operational effectiveness is a question mark due to the fact that the concept of recycling and accompanying awareness is low, people do not understand well in general how the process of recycling works and the importance of sorting the waste itself. The existing functioning facilities mostly receive commingled SW and then separate the organics from the recyclables on the site, reducing the quantity and the quality of the recovered material.

For the present study, the three most common construction materials analysed from the recycling perspective are asphalt, timber and metal. The asphalt is a fully recyclable material which great properties for reuse/recycle. The use of recycled asphalt in road industry is an economically effective solution, leading to significant savings where applied. Different technologies can be used in recycling asphalt materials, including cold recycling and heat generation. The cold recycling technology is an economical option to recycle the asphalt, allowing up to $100 \%$ recycling. However, it requires the old asphalt to be first crushed. The heat generation technologies include the Minnesota process, parallel drum process, elongated drum process, microwave asphalt and surface regeneration. All these options are used prior heating and can process the new asphalt by a mobile plant treatment [46], therefore they can be recommended for more effective C\&DW management as well.

In the construction site, timber is usually found mixed with other construction materials. Therefore, separation is intense and time-consuming work. Overall, there are four recovery options for wood waste: reuse, direct recycling, indirect recycling and energy recovery [47]. The energy recovery seems like the best option for the present case.

The main metals that can be recovered from C\&DW are aluminium, copper, lead and zinc [46]. These metals can be sold to third parties that will further perform reusing and recycling operations. For example, in the UK the recycling rate of aluminium is $70 \%$, copper's $100 \%$, lead $85 \%$, whereas zinc can be reused for roofing cladding, extent flashing and production of brass [48]. The CC started selling metal, plastic and other materials in 2016 resulting in significant savings. It is recommended for the $\mathrm{CC}$ to sort the metal on the site with higher efficiency in the following years. According to the analyses conducted with the CC, if sorting is done in the conventional way by hand, the recovery rate varies from $5 \%$ to $50 \%$ and averaging around $20 \%$, the rest being disposed to landfill. This indicates a significant room for improvement for the CC. Using business-to-business refund systems (similar to deposit-refund systems often integrated in business-to-consumer systems encouraging end consumers to return especially plastic, metals and glass for a refund) would significantly promote waste recycling and thus help achieving higher recycling percentages. To increase the on-site sorting rate of metals, magnetic separation techniques should be implemented. This way, based on the observed composition of the waste, we assume that the average sorting rate can be improved from the current $20 \%$ to up to $80 \%$.

\section{Conclusions and Implications}

The present study presents a comprehensive C\&DW management assessment approach while discussing the lessons learned from existing construction waste management practices in one of the leading construction companies operating in Central Asia (the case company (CC) with the head office located in Kazakhstan). It investigates several C\&DW practices both based on the literature and in terms of their satisfactory and unsatisfactory results after their adaption. It does this by considering external and internal organizational dynamics (PESTEL) and by reviewing various approaches and results of the practices at operational level from the waste management hierarch (3R) perspective in the context of Kazakhstan construction sector.

For the present study, firstly supporting proofs of good waste management practices from studies conducted in different countries have been reviewed; and subsequently, several successful waste 
management practices have been identified, then presented in figures and tables, some of which having been then tried and adapted by the CC. Although good practices vary to an extent among countries and continents, they all share a common hierarchical approach and can be systematized into the steps of reduce, reuse and recycle; also known as the 3R strategy. The CC has high volumes of construction operations and was generating very large amounts of C\&DW. On top of that, the cost of waste management activities was growing at a rate higher than of construction materials purchases. Following the acknowledgement of the problem and starting the implementation of some waste management approaches, some success has been achieved. However, due to the low level of incentives and opportunities for sustainable waste management practices in the nation's government level and the absence of "green practices" in the nation's sectoral level, the CC also faced external barriers hampering their efforts in sustainability. There were also internal problems caused by the absence of a common waste management approach/model, a lack of expertise and best practices and some reluctance from the employees and from the organizational structure. It can be assumed that the successes as well as current challenges can be effectively extrapolated to other construction companies functioning in the economically booming countries of Central Asia and the good practices identified here as well as recommendations made are applicable within the region. In the long term, the benefits of strategically implementing solutions based on the 3R strategy to the C\&DW management issues of the Central Asian construction sector will bring significant tangible and intangible benefits.

The most significant findings from the present case study based on the Kazakh CC but also highly applicable to other construction companies operating in the rest of the Central Asia can be summarized as follows:

- PESTEL analysis has shown that according to the external and internal drivers analysis, although an "official" vision exists in Kazakhstan towards establishing a waste management guideline, there is still a significant gap in construction industry between the current and the ideal levels of C\&DW management practices due to insufficient technological factors prepossessing recycle of waste, a low degree of development of a 'green culture,' a lack of awareness and an absolute absence of incentives from legal and economic sides.

- The activities promoting waste reduction seems to have the largest potential to minimize C\&DW (compared to reuse and recycling). Since one of the main sources of C\&DW is inadequate or faulty design, the BIM technology is highly promising to eliminate related problems early at the design stage.

- The potential of BIM as a reduction strategy is also significant as it already renders some later reuse and recycle activities unnecessary as it leads to reduction at the beginning. Prefabricated construction is also encouraged for waste reduction but its implementation seems less significant than BIM for the moment.

- Though some initial measures successfully and significantly reduced the total C\&DW, the generation was still high due to issues discussed in detail in the text, thus further measures in reuse and recycling are also encouraged.

- Concrete was the main material for reuse as it can serve as aggregate to produce new concrete. As the CC already has the crushing equipment, the continuation of its use and applications including alternative applications is recommended (e.g., new concrete, for temporary roads, as backfill, as sub-base). Drywall also has some potential but to a lesser extent than concrete.

- Other materials such as asphalt, wood and metal have significant reuse and/or recycling potential. Especially the off-site recycling potential of metals (i.e., material to be sold to third parties for recycling) is not yet exploited to its full extent of possibility.

- Employee awareness regarding 3R hierarchy and waste management seems low regardless of the level of the employee. Already implemented training programs would likely to be successful and yet needs to be repeated due to high employee turnover in the sector. 
Author Contributions: Conceptualization, A.T. and F.K.; Data curation, Z.B, A.S. and G.S.; Formal analysis, Z.B. and A.S.; Investigation, G.S.; Methodology, A.T.; Project administration, G.S.; Resources, A.T.; Supervision, A.T.; Validation, M.G.; Visualization, F.K. and Z.B.; Writing-original draft, M.G., Z.B., A.S. and G.S.; Writing-review \& editing, A.T., M.G. and F.K.

Funding: This research received no external funding. The APC was funded by Nazarbayev University.

Conflicts of Interest: The authors declare no conflict of interest.

\section{References}

1. UNEP; ISWA. Global Waste Management Outlook; United Nations Environment Programme: Vienna, Austria, 2015.

2. Jin, R.; Yuan, H.; Chen, Q. Science mapping approach to assisting the review of construction and demolition waste management research published between 2009 and 2018. Resour. Conserv. Recycl. 2019, 140, 175-188. [CrossRef]

3. Ferronato, N.; Rada, E.C.; Gorritty Portillo, M.A.; Cioca, L.I.; Ragazzi, M.; Torretta, V. Introduction of the circular economy within developing regions: A comparative analysis of advantages and opportunities for waste valorization. J. Environ. Manag. 2019, 230, 366-378. [CrossRef] [PubMed]

4. Horvath, A. Construction Materials and The Environment. Annu. Rev. Environ. Resour. 2004, 29, 181-204. [CrossRef]

5. Thongkamsuk, P.; Sudasna, K.; Tondee, T. Waste generated in high-rise buildings construction: A current situation in Thailand. Energy Procedia 2017, 138, 411-416. [CrossRef]

6. EC Waste. Available online: http://ec.europa.eu/environment/waste/construction_demolition.htm (accessed on 10 January 2019).

7. EPD Statistics Unit. Monitoring of Solid Waste in Hong Kong-Waste Statistics for 2014; Environmental Protection Department: Hong Kong, China, 2015.

8. Rogers, S. Battling construction waste and winning: Lessons from UAE. Proc. Inst. Civ. Eng. Eng. 2011, 164, 41-48. [CrossRef]

9. Giannis, A.; Chen, M.J.; Yin, K.; Tong, H.H.; Veksha, A. Application of system dynamics modelling for evaluation of different recycling scenarios in Singapore. J. Mater. Cycles Waste Manag. 2017, 19, 1177-1185. [CrossRef]

10. Manowong, E. Investigating factors influencing construction waste management efforts in developing countries: An experience from Thailand. Waste Manag. Res. 2012, 30, 56-71. [CrossRef] [PubMed]

11. Tam, V.W.Y. Economic comparison of concrete recycling: A case study approach. Resour. Conserv. Recycl. 2008, 52, 821-828. [CrossRef]

12. Hoornweg, D.; Bhada-Tata, P. What a Waste: A Global Review of Solid Waste Management. Urban development series. World Bank 2012, 1, 1-116.

13. Khandelwal, H.; Dhar, H.; Thalla, A.K.; Kumar, S. Application of Life Cycle Assessment in Municipal Solid Waste Management: A Worldwide Critical Review. J. Clean. Prod. 2018, 209, 630-654. [CrossRef]

14. Jia, S.; Liu, X.; Yan, G. Dynamic analysis of construction and demolition waste management model based on system dynamics and grey model approach. Clean Technol. Environ. Policy 2018, 20, 2089-2107. [CrossRef]

15. Kim, J.; Tae, S.; Kim, R. Theoretical Study on the Production of Environment-Friendly Recycled Cement Using Inorganic Construction Wastes as Secondary Materials in South Korea. Sustainability 2018, 10, 4449. [CrossRef]

16. Ibrahim, M. Estimating the sustainability returns of recycling construction waste from building projects. Sustain. Cities Soc. 2016, 23, 78-93. [CrossRef]

17. UNEP. Central Asia Waste Management Outlook; ZOI Environment Network: Châtelaine, Switzerland, 2017.

18. Makhmutova, E.V. Central Asia in Search for Its Own Way of Integration. Mgimo Rev. Int. Relat. 2018, 78-91.

19. Gálvez-Martos, J.L.; Styles, D.; Schoenberger, H.; Zeschmar-Lahl, B. Construction and demolition waste best management practice in Europe. Resour. Conserv. Recycl. 2018, 136, 166-178. [CrossRef]

20. Ministry of Justice of the Republic of Kazakhstan. Environmental Code of the Republic of Kazakhstan; ILS Adilet: Astana, Kazakhstan, 2007. 
21. Inglezakis, V.J.; Moustakas, K.; Khamitovac, G.; Tokmurzin, D.; Rakhmatulina, R.; Serik, B.; Abikak, Y.; Poulopoulos, S.G. Municipal solid waste management in Kazakhstan: Astana and almaty case studies. Chem. Eng. Trans. 2017, 56, 565-570.

22. Inglezakis, V.J.; Moustakas, K.; Khamitova, G.; Tokmurzin, D.; Sarbassov, Y.; Rakhmatulina, R.; Serik, B.; Abikak, Y.; Poulopoulos, S.G. Current municipal solid waste management in the cities of Astana and Almaty of Kazakhstan and evaluation of alternative management scenarios. Clean Technol. Environ. Policy 2018, 20, 503-516. [CrossRef]

23. Gi Llespie PESTEL Analysis of the Macro-Environment; Oxford University Press: Oxford, UK, 2011; pp. 1-5.

24. Carruthers, H. Using PEST analysis to improve business performance. Practice 2009, 31, 37-39. [CrossRef]

25. Iacovidou, E.; Busch, J.; Hahladakis, J.N.; Baxter, H.; Ng, K.S.; Herbert, B.M.J. A Parameter Selection Framework for Sustainability Assessment. Sustainability 2017, 9, 1497. [CrossRef]

26. Buchanan, S.; Gibb, F. The information audit: Methodology selection. Int. J. Inf. Manag. 2008, 28, 3-11. [CrossRef]

27. Udawatta, N.; Zuo, J.; Chiveralls, K.; Zillante, G. Improving waste management in construction projects: An Australian study. Resour. Conserv. Recycl. 2015, 101, 73-83. [CrossRef]

28. Wang, J.Y.; Kang, X.P.; Tam, V.W.Y. An investigation of construction wastes: An empirical study in Shenzhen. J. Eng. Des. Technol. 2008, 6, 227-236. [CrossRef]

29. Peng, C.L.; Scorpio, D.E.; Kibert, C.J. Strategies for successful construction and demolition waste recycling operations. Constr. Manag. Econ. 1997, 15, 49-58. [CrossRef]

30. Huang, B.; Wang, X.; Kua, H.; Geng, Y.; Bleischwitz, R.; Ren, J. Construction and demolition waste management in China through the 3R principle. Resour. Conserv. Recycl. 2018, 129, 36-44. [CrossRef]

31. Memon, M.A. Integrated solid waste management based on the $3 \mathrm{R}$ approach. J. Mater. Cycles Waste Manag. 2010, 12, 30-40. [CrossRef]

32. Shan, N.L.; Wee, S.T.; Wai, T.L.; Chen, G.K. Construction Waste Management of Malaysia: Case Study in Penang. Adv. Sci. Lett. 2018, 24, 4698-4703. [CrossRef]

33. Osmani, M. Construction Waste. In Waste: A Handbook for Management; Letcher, T.M., Vallero, D.A., Eds.; Elsevier Inc.: Burlington, MA, USA, 2011; pp. 207-218. ISBN 9780123814753.

34. Rounce, G. Quality, waste and cost considerations in architectural building design management. Int. J. Proj. Manag. 1998, 16, 123-127. [CrossRef]

35. Keys, A.; Baldwin, A. Designing to encourage waste minimisation in the construction industry. In Proceedings of the CIBSE National Conference, CIBSE2000, Dublin, Ireland, 4-5 September 2000.

36. Ekanayake, L.L.; Ofori, G. Building waste assessment score: Design-based tool. Build. Environ. 2004, 39, 851-861. [CrossRef]

37. Eastman, C.M.; Teicholz, P.; Sacks, R.; Liston, K. BIM Handbook: A guide to Building Information Modeling for owners, managers, designers, engineers and contractors, 2nd ed.; Wiley \& Sons: Hoboken, NJ, USA, 2011; ISBN 9780470541371.

38. Won, J.; Cheng, J.C.P.; Lee, G. Quantification of construction waste prevented by BIM-based design validation: Case studies in South Korea. Waste Manag. 2016, 49, 170-180. [CrossRef] [PubMed]

39. Cheng, J.C.P.; Won, J.; Das, M. Construction and Demolition Waste Management using BIM technology. Waste Manag. N. Y. 2015, 27, 159-160.

40. Jaillon, L.; Poon, C.S.; Chiang, Y.H. Quantifying the waste reduction potential of using prefabrication in building construction in Hong Kong. Waste Manag. 2009, 29, 309-320. [CrossRef] [PubMed]

41. Lawton, T.; Moore, P.; Cox, K.; Clark, J. The gammon skanska construction system. In Proceedings of the International Conference Advances in Building Technology, Hong Kong, China, 4-6 December 2002; Volume 2, pp. 1073-1080, ISBN 978-0-08-044100-9.

42. Lachimpadi, S.K.; Pereira, J.J.; Taha, M.R.; Mokhtar, M. Construction waste minimisation comparing conventional and precast construction (Mixed System and IBS) methods in high-rise buildings: A Malaysia case study. Resour. Conserv. Recycl. 2012, 68, 96-103. [CrossRef]

43. Cochran, K.M. Construction and demolition debris recycling: Methods, markets and policy. Diss. Abstr. Int. B Sci. Eng. 2009, 70, 1260.

44. Tam, V.W.Y.; Tam, C.M. Evaluations of existing waste recycling methods: A Hong Kong study. Build. Environ. 2006, 41, 1649-1660. [CrossRef] 
45. Marvin, E. Gypsum Wallboard Recycling and Reuse Opportunities in the State of Vermont; Vermont Agency of Natural Resources: Montpelier, VT, USA, 2000.

46. Tam, V.W.Y.; Tam, C.M. A review on the viable technology for construction waste recycling. Resour. Conserv. Recycl. 2006, 47, 209-221. [CrossRef]

47. Taylor, J.; Mann, R.; Reilly, M.; Warnken, M.; Pincic, D.; Death, D. Recycling and End-of-Life Disposal of Timber Products; Forest and Wood Products Research and Development Corporation: Melbourne, Australia, 2005.

48. Lang, J.C. Zero landfill, zero waste: The greening of industry in Singapore. Green. Ind. New Ind. Econ. Asian-Style Leapfrogging 2014, 4, 189-215. [CrossRef]

(C) 2019 by the authors. Licensee MDPI, Basel, Switzerland. This article is an open access article distributed under the terms and conditions of the Creative Commons Attribution (CC BY) license (http:/ / creativecommons.org/licenses/by/4.0/). 